Check for updates

Cite this: RSC Adv., 2017, 7, 41546

Received 13th July 2017

Accepted 19th August 2017

DOI: $10.1039 / \mathrm{c} 7 \mathrm{ra07684c}$

rsc.li/rsc-advances

\title{
Dehydration of glucose to 5-hydroxymethylfurfural and 5-ethoxymethylfurfural by combining Lewis and Brønsted acid
}

\author{
Haosheng Xin, ab Tingwei Zhang, (D) ${ }^{b}$ Wenzhi Li, (DD *b Mingxue Su, ${ }^{b}$ Song Li, \\ Qun Shao*a and Longlong $\mathrm{Ma}^{\mathrm{C}}$
}

In this work, glucose was transformed into 5-hydroxymethylfurfural (HMF) and 5-ethoxymethylfurfural (EMF) in the presence of $\mathrm{AlCl}_{3} \cdot 6 \mathrm{H}_{2} \mathrm{O}$ and a Brønsted solid acid catalyst (PTSA-POM). GVL $(\gamma$-valerolactone)-water and ethanol-water solvent systems were evaluated in the dehydration reaction of glucose into $\mathrm{HMF}$ and EMF, respectively. Water content and dosage of $\mathrm{AlCl}_{3} \cdot 6 \mathrm{H}_{2} \mathrm{O}$ were examined in the conversion of glucose into $\mathrm{HMF}$, and some valuable chlorides $\left(\mathrm{FeCl}_{3} \cdot 6 \mathrm{H}_{2} \mathrm{O}, \mathrm{NiCl}_{2} \cdot 6 \mathrm{H}_{2} \mathrm{O}, \mathrm{CrCl}_{3} \cdot 6 \mathrm{H}_{2} \mathrm{O}\right.$ etc.) were also used in contrast with $\mathrm{AlCl}_{3} \cdot 6 \mathrm{H}_{2} \mathrm{O}$. Some different organic solvents were added to the ethanol-water system to explore whether it would be beneficial to the generation of EMF. A high yield of HMF (60.7\%) was obtained at $140{ }^{\circ} \mathrm{C}$ within 60 min in GVL-water $(10: 1)$ solvent system, and total yield $42.1 \%$ of EMF and $\mathrm{HMF}\left(30.6 \% \mathrm{EMF}, 11.5 \% \mathrm{HMF}\right.$ ) was achieved at $150{ }^{\circ} \mathrm{C}$ after $30 \mathrm{~min}$ in an ethanolwater $(9: 1)$ solvent system.

\section{Introduction}

Urged by the rapid depletion of fossil fuels and increased environmental issues, great efforts have been devoted to the production of sustainable biofuels from biomass. ${ }^{1,2}$ In comparison with other sugars, glucose is the most abundant hexose contained in lignin biomass, considered as the most valuable bio-derived carbon resource, and it plays a vital role in the conversion of biomass to biofuels and chemicals. ${ }^{3-5}$ Thus, the high-efficiency transformation of glucose to platform chemicals has aroused much attention in recent years. ${ }^{6}$ Among those prospective chemicals, HMF and EMF are thought highly of as promising building blocks for the application of renewable resources.

5-hydroxymethylfurfural (HMF), a valuable biomass-derived platform compound, referred as the bridge between renewable resources and chemistry chemicals. ${ }^{7-9}$ Glucose, a most widely distributed monosaccharide in nature, has been exploited in the production of HMF and furan compounds. ${ }^{10}$ There are two ways to convert glucose to HMF, one is direct dehydration of glucose to HMF; the other mainly comprises two steps, firstly, glucose is isomerized to fructose, after that, HMF

\footnotetext{
${ }^{a}$ Institute of Materials and Chemical Engineering, Anhui Jianzhu University, Hefei 230022, China

${ }^{b}$ Laboratory of Basic Research in Biomass Conversion and Utilization, Department of Thermal Science and Energy Engineering, University of Science and Technology of China, Hefei 230026, China. E-mail: liwenzhi@ustc.edu.cn

${ }^{c}$ CAS Key Laboratory of Renewable Energy, Guangzhou Institute of Energy Conversion, Chinese Academy of Sciences, Guangzhou 510640, China
}

can be obtained in the dehydration of fructose. ${ }^{11}$ Compared to the one-step method, the current two-step process is studied more extensively and Lewis acid plays a vital role for the isomerization of glucose into fructose in two-step process. ${ }^{12}$ Therefore, the combination of Lewis acid and Brønsted acid is extremely important in order to transform glucose efficiently. ${ }^{13}$ Nikolla et al. exploited the synthesis of HMF from glucose in the combination of $\mathrm{HCl}$ and Sn-beta catalyst in $\mathrm{THF} / \mathrm{H}_{2} \mathrm{O}-\mathrm{NaCl}$ system, HMF yield (56.9\%) and glucose conversion (79\%) was obtained after $70 \mathrm{~min}$ at $180{ }^{\circ} \mathrm{C} .{ }^{14}$ In contrast to homogeneous catalyst $\left(\mathrm{HCl}, \mathrm{H}_{2} \mathrm{SO}_{4}, \mathrm{H}_{3} \mathrm{PO}_{4}\right)$, solid acid catalyst shows many advantages such as low corrosivity to the reactor, easy separation after reaction and more stable at high temperatures. ${ }^{15}$ Thus, the production of HMF over solid acid catalysts have been studied diffusely in recent years. Ohara et al. synthesized a catalyst with combination of Amberlyst- 15 and hydrotalcite to catalyze glucose to HMF in DMF solvent system, HMF yield (41\%) and glucose conversion (71\%) was achieved at $373 \mathrm{~K}$ in 3 h. ${ }^{16}$ Thombal et al. prepared a solid acidic catalyst by mixing $\beta$-cyclodextrin and $p$-toluenesulfonic acid, with a reaction time of $5 \mathrm{~h}$ at $453 \mathrm{~K}$, the HMF yield was $47 \%$ in DMSO. ${ }^{17}$ In addition, enormous attention was paid to ionic liquids (ILs) in recent period time. By combining and modifying the cations and anions properly, the properties of obtained ILs (polarity, hydrophobicity and dissolving capacity) could be fit better to adapt to the reaction. ${ }^{18-21}$ Detail works with careful design of IL has been done systemic which demonstrated that the transformation of glucose to HMF could be enhanced significantly. ${ }^{22,23}$ Zhang et al. prepared a heterogeneous catalyst (CrHAP) by combining hydroxyapatite and chromium chloride, 
and the catalyst was used in the dehydration of glucose in [BMIM]Cl, HMF yield of $40.2 \%$ with glucose conversion of $77.9 \%$ were obtained in $2.5 \mathrm{~min}$ with the aid of microwave irradiation. ${ }^{24}$ Chen et al. utilized $\mathrm{Cr}(\mathrm{CO})_{6}$ as catalyst for the transformation of glucose into HMF in [EMIM]Cl, after $6 \mathrm{~h}$ at $120{ }^{\circ} \mathrm{C}$, affording the HMF yield of $50 \% .^{25}$ Although ILs has achieved great progress, its exorbitant price impose restrictions on the production of HMF and subsequent separation after reaction is also difficult. In this work, HMF is also a crucial intermediate product in the process of glucose conversion to EMF.

5-ethoxymethylfurfural (EMF), regarded as fuels or fuel additives, has high energy density $\left(8.7 \mathrm{~kW} \mathrm{~h} \mathrm{~L}^{-1}\right)$ close to diesel (9.7 $\left.\mathrm{kW} \mathrm{h} \mathrm{L}^{-1}\right)$ and regular gasoline $\left(8.8 \mathrm{~kW} \mathrm{~h} \mathrm{~L}^{-1}\right)$, far better than ethanol $\left(6.1 \mathrm{~kW} \mathrm{~h} \mathrm{~L}{ }^{-1}\right) .{ }^{26}$ According to the previous literatures, EMF was mainly synthesized not directly from carbohydrates, the intermediate products such as HMF, 5(chloromethyl)furfural (CMF) and 5-(bromomethyl)furfural $\mathrm{BMF}$ were firstly obtained, and then etherified into EMF. ${ }^{27-31} \mathrm{Liu}$ et al. studied the EMF production from HMF, fructose and glucose, respectively. ${ }^{32}$ In accordance with expectation, the reaction efficient improved in the order: glucose $<$ fructose $<$ HMF. Compared with fructose and HMF, glucose has a good stability and pricing advantage in the formation of EMF. In the earlier time, Christopher M. Lew et al. used Sn-BEA and Amberlyst-131 as catalysts to catalyze glucose into EMF in a single reactor at $90{ }^{\circ} \mathrm{C}, 31 \%$ yield of EMF was achieved after $24 \mathrm{~h} .{ }^{33}$ For the long time cost and low yield of EMF, people were inspired to hammer at ameliorating catalyst. In Yan's work, $\mathrm{CrCl}_{3}$ showed excellent catalytic efficiency in the conversion of carbohydrates. ${ }^{34}$ But as it known to us, Cr belongs to heavy metal and do harm to the environment with some toxicity. Recently, via the good deal of work of Yu Yang and $\mathrm{Hu}, \mathrm{Li}$, $\mathrm{AlCl}_{3} \cdot 6 \mathrm{H}_{2} \mathrm{O}$ was also proved to be a preeminent catalyst in the production of EMF, high yield with expectation achieved. ${ }^{35,36}$

Both HMF and EMF are the vital platform chemicals in the conversion of carbohydrates, of which is worthy studied in depth, furthermore, EMF was obtained in the further etherification of HMF. ${ }^{14-21,24,25,27-36}$ And the study of direct conversion from glucose to EMF is particularly deserved. Thus, in this study, the dehydration of glucose to HMF was investigated by regulating reaction times, temperatures and the ratio of deionized water to organic solvent, some valuable chlorides $\left(\mathrm{FeCl}_{3} \cdot 6 \mathrm{H}_{2} \mathrm{O}, \mathrm{SnCl}_{4} \cdot 5 \mathrm{H}_{2} \mathrm{O}, \mathrm{CrCl}_{3} \cdot 6 \mathrm{H}_{2} \mathrm{O}\right.$, etc. $)$ were also been compared. The further etherification from HMF to EMF in the process of glucose conversion was also explored in ethanol $/ \mathrm{H}_{2} \mathrm{O}$. Apart from the influence of reaction times and temperatures, DMSO, dioxane, THF, MIBK, GVL were added extra to ethanol/ $\mathrm{H}_{2} \mathrm{O}$ to explore the influence of added second organic solvent.

Previously, in the transformation of corn stalk into furfural, our group prepared a novel heterogeneous strong acid catalyst (PTSA-POM) by polymerizing $p$-toluenesulfonic acid (PTSA) and paraformaldehyde (POM) in the presence of $\mathrm{H}_{2} \mathrm{SO}_{4}$, and achieved significant results. ${ }^{37}$ Due to its easy preparation and excellent recyclability, the further application of PTSA-POM was explored in the dehydration of glucose in this paper. As for solvent, $\gamma$-valerolactone (GVL), a green solvent that can be obtained from biomass, was selected and proved to be a good solvent in the conversion of carbohydrates into furan compounds. ${ }^{38-40}$ Ethanol plays a decisive role in the etherification of HMF to EMF, not only acted as a green solvent, but also as a reactant.

\section{Experimental}

p-toluenesulfonic acid monohydrate (PTSA $\left.\cdot \mathrm{H}_{2} \mathrm{O}, 98.5 \%\right)$, paraformaldehyde (POM, AR), D-(+)-glucose (GC, 99.5\%), HMF (99\%), EMF (97\%) were purchased from Aladdin Industrial, Inc. (Shanghai, China). GVL (95\%) was obtained from LangFang Hawk Technology and Development Co, Ltd. $\mathrm{AlCl}_{3} \cdot 6 \mathrm{H}_{2} \mathrm{O}(\mathrm{AR})$, $\mathrm{CrCl}_{3} \cdot 6 \mathrm{H}_{2} \mathrm{O}(\mathrm{AR}), \quad \mathrm{CrCl}_{2}(\mathrm{AR}), \quad \mathrm{MgCl}_{2} \cdot 6 \mathrm{H}_{2} \mathrm{O}(\mathrm{AR}), \quad \mathrm{CaCl}_{2}(\mathrm{AR})$, $\mathrm{NiCl}_{2} \cdot 6 \mathrm{H}_{2} \mathrm{O}(\mathrm{AR}), \quad \mathrm{NH}_{4} \mathrm{Cl}(\mathrm{AR}), \quad \mathrm{FeCl}_{3} \cdot 6 \mathrm{H}_{2} \mathrm{O}(\mathrm{AR}), \quad \mathrm{CoCl}_{2} \cdot 6 \mathrm{H}_{2}$ $\mathrm{O}(\mathrm{AR}), \mathrm{MnCl}_{2} \cdot 4 \mathrm{H}_{2} \mathrm{O}(\mathrm{AR}), \mathrm{SnCl}_{4} \cdot 5 \mathrm{H}_{2} \mathrm{O}(\mathrm{AR}), \mathrm{SnCl}_{2} \cdot 2 \mathrm{H}_{2} \mathrm{O}(\mathrm{AR})$, $\mathrm{H}_{2} \mathrm{SO}_{4}$ (96-98\%, AR), MIBK(AR), THF(AR), DMSO(AR) and dioxane(AR) were supplied by Sinopharm Chemical Reagent Co., Ltd (Shanghai, China). All the chemicals were used without further purification.

According to our reported literature, ${ }^{37}$ the details of synthesis of PTSA-POM as following: firstly, $0.2 \mathrm{ml}$ sulphuric acid (98\%) and $10.0 \mathrm{~g}$ PTSA- $\mathrm{H}_{2} \mathrm{O}$ were put to a three-necked roundbottomed flask with magnetic stirring and reflux condensation which was heated at $110{ }^{\circ} \mathrm{C}$. Then $4 \mathrm{~g}$ POM added immediately after PTSA- $\mathrm{H}_{2} \mathrm{O}$ melted completely. The reaction temperature was kept at $110{ }^{\circ} \mathrm{C}$ for $8 \mathrm{~h}$, then adjusted to $130{ }^{\circ} \mathrm{C}$ for $24 \mathrm{~h}$ to form a black solid. After that, the obtained solid was filtered and washed to $\mathrm{pH}=7$ with deionized water. Drying at $120{ }^{\circ} \mathrm{C}$ is necessary and then ground to powder. Finally, the resulting sample was calcined in muffle at $185{ }^{\circ} \mathrm{C}$ for $6 \mathrm{~h}$.

For the production of HMF, reactions were carried out in a $48 \mathrm{ml}$ pressure thick wall tube with oil-bath heating accompanied by $500 \mathrm{rpm}$ magnetic stirring. As for EMF, because of the high temperature, a certain pressure will be produced in the reaction process by ethanol. Therefore, taking security into account, glucose, catalysts and solvents were loaded and sealed in a $25 \mathrm{ml}$ autoclave. The autoclave was heated to desired temperature from room temperature in $30 \mathrm{~min}$ and also stirred magnetically at $500 \mathrm{rpm}$. After the reaction, both tube and autoclave were immersed in cold water immediately to terminate the reaction. Diluted and filtered liquid was analyzed using HPLC.

HPLC (waters 515 pump, equipped with an UV/Vis Detector (Waters 2489) using Waters Symmetry-C18 column $(5 \mu \mathrm{m}, 4.6 \times$ $150 \mathrm{~mm}$ ) and a Rrefractive Index Detector (Waters 2414) using Waters XBridge Amide column $(5 \mu \mathrm{m}, 4.6 \times 150 \mathrm{~mm})$ ) was used to analyze diluted samples for HMF yield, EMF yield and glucose conversion. ${ }^{33-35}$ Authentic samples of HMF and EMF were used as standards, which calibration curves were applied to quantify.

HMF yield, EMF yield and glucose conversion were calculated as follows:

HMF yield $=$ (moles of HMF in products/ moles of initial glucose) $\times 100 \%$, 
$\mathrm{EMF}$ yield $=$ (moles of EMF in products/ moles of initial glucose) $\times 100 \%$,

$\mathrm{HMF}$ selectivity $=(\mathrm{HMF}$ yield/glucose conversion $) \times 100 \%$

Glucose conversion $=1-($ moles of glucose in products $/$ moles of initial glucose) $\times 100 \%$

\section{Results and discussion}

Except the dosage of $\mathrm{AlCl}_{3} \cdot 6 \mathrm{H}_{2} \mathrm{O}$, other parameters employed in the reaction are on the basis of previous literatures of our group. ${ }^{37,39}$ Initially, in order to make the dosage of $\mathrm{AlCl}_{3} \cdot 6 \mathrm{H}_{2} \mathrm{O}$ appropriately, some probe trials at a mild temperature $140{ }^{\circ} \mathrm{C}$ with 20 min were explored in autoclave.

The results are shown in Table 1 , as it showing to us (entry 3), a maximum yield was obtained when $0.15 \mathrm{~g} \mathrm{AlCl}_{3} \cdot 6 \mathrm{H}_{2} \mathrm{O}$ was loaded. Herein, $0.15 \mathrm{~g}$ dosage of $\mathrm{AlCl}_{3} \cdot 6 \mathrm{H}_{2} \mathrm{O}$ was adopted in the further reactions.

Production of HMF from the dehydration of glucose was carried out at $130{ }^{\circ} \mathrm{C}, 140{ }^{\circ} \mathrm{C}$ and $150{ }^{\circ} \mathrm{C}$, with time from $30 \mathrm{~min}$ to $90 \mathrm{~min}$ (10 min interval), respectively, both HMF yield and glucose conversion are shown in Fig. 1. Obviously, according to

Table 1 Effect of $\mathrm{AlCl}_{3} \cdot 6 \mathrm{H}_{2} \mathrm{O}$ dosage on the dehydration of glucose into $\mathrm{HMF}^{a}$

\begin{tabular}{lll}
\hline Entry & Dosage & Yield/\% \\
\hline 1 & $0.05 \mathrm{~g}$ & 50.3 \\
2 & $0.10 \mathrm{~g}$ & 54.0 \\
3 & $0.15 \mathrm{~g}$ & 57.8 \\
4 & $0.20 \mathrm{~g}$ & 54.3 \\
5 & $0.25 \mathrm{~g}$ & 51.7 \\
6 & $0.30 \mathrm{~g}$ & 49.4
\end{tabular}

${ }^{a}$ Reaction conditions: $0.4 \mathrm{~g}$ glucose, $0.2 \mathrm{~g}$ PTSA-POM, $15 \mathrm{ml} \mathrm{GVL}$ and $1.5 \mathrm{ml}$ DIW, $140{ }^{\circ} \mathrm{C}$ (30 min heating-up time), $20 \mathrm{~min}, 500 \mathrm{rpm}$. the lines, it can be seen that temperature has profound impact on HMF yield. At $130{ }^{\circ} \mathrm{C}, \mathrm{HMF}$ yield increased with the increase of reaction time, but relatively low HMF yield was obtained even in $90 \mathrm{~min}$. By comparison, when the temperature are $140{ }^{\circ} \mathrm{C}$ and $150{ }^{\circ} \mathrm{C}$, with reaction time goes by, HMF yield firstly increased, and decreased severally after reached the optimal values. Indicated that in higher temperatures, prolonged reaction time firstly promoted the transformation of glucose to HMF, after reached the optimal values, the effect of time on the reaction is not as obvious as at low temperature on HMF production. Throughout the whole reactions, highest yield $60.7 \%$ of HMF was achieved at $140{ }^{\circ} \mathrm{C}$ in a short time (60 min).

Glucose is well converted in $\mathrm{GVL} / \mathrm{H}_{2} \mathrm{O}$ solution and almost all the reactions conversion were over $90 \%$ even though the temperature was as low as $130{ }^{\circ} \mathrm{C}$. As for higher temperature of $140^{\circ} \mathrm{C}$ and $150^{\circ} \mathrm{C}$, complete conversion of glucose was achieved both in $60 \mathrm{~min}$. It was clear that higher temperatures is more conducive to the conversion of glucose.

In this section, based on the optimal conditions found above, comparative experiment was also made on acid added. The results are shown in Table 2. From which we can learn that the yield of HMF was much promoted on the dehydration of glucose by combining PTSA-POM and $\mathrm{AlCl}_{3} \cdot 6 \mathrm{H}_{2} \mathrm{O}$, compared with only PTSA-POM or $\mathrm{AlCl}_{3} \cdot 6 \mathrm{H}_{2} \mathrm{O}$ added. To our knowledge, compared with PTSA-POM, glucose is isomerized to fructose easily in the presence of $\mathrm{AlCl}_{3} \cdot 6 \mathrm{H}_{2} \mathrm{O}$, and some $\mathrm{H}^{+}$will also be formed when $\mathrm{AlCl}_{3} \cdot 6 \mathrm{H}_{2} \mathrm{O}$ dissolved in water, and the production of $\mathrm{HMF}$ from fructose is easy to carry out in $\mathrm{GVL} / \mathrm{H}_{2} \mathrm{O}$ with $\mathrm{H}^{+}$. Then, with PTSA-POM added, the dehydration of fructose to HMF could be enhanced and the yield of HMF could be promoted. Therefore, the activity in the reaction may due to the conjunction of these two acids.

Apart from the effects of temperature and time, we judged that different water content could also has a significant influence on the dehydration of glucose to HMF. In view of this conjecture, great deal of efforts was made for the study of the effect of different water content. The results were summarized at Table 3, and results are highly consistent with our expectations, water added has a significant effect on HMF production.
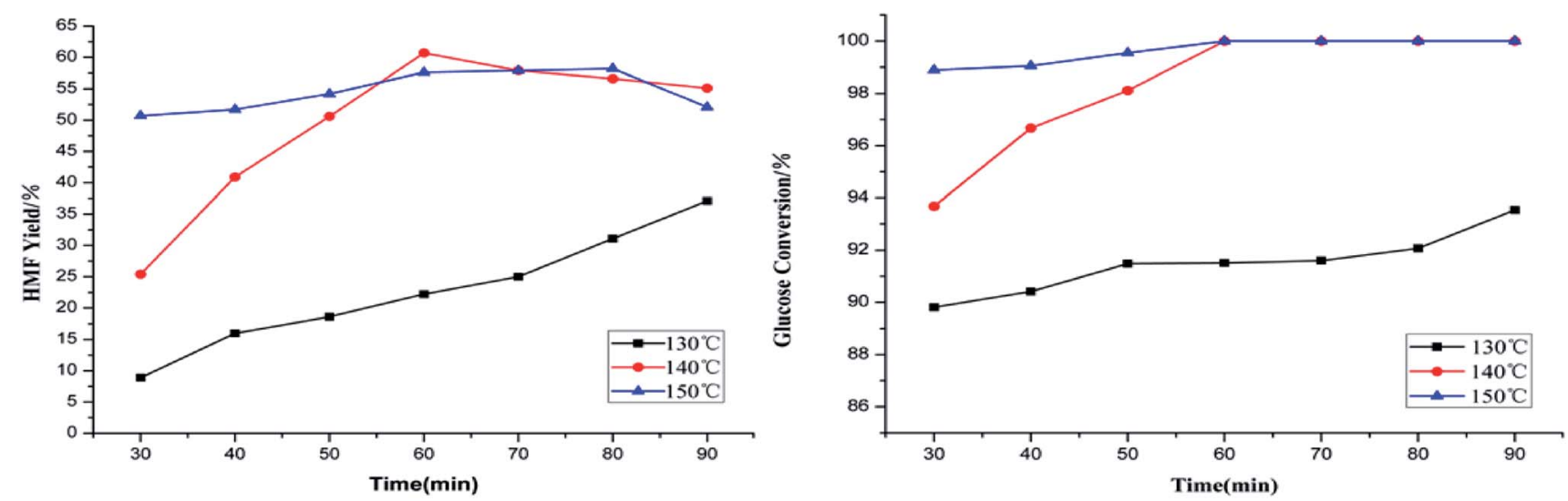

Fig. 1 Effects of temperature and time on the conversion of glucose into HMF. Reaction conditions: $0.4 \mathrm{~g}$ glucose, $0.2 \mathrm{~g}$ PTSA-POM, $0.15 \mathrm{~g}$ $\mathrm{AlCl}_{3} \cdot 6 \mathrm{H}_{2} \mathrm{O}, 15 \mathrm{ml} \mathrm{GVL}$ and $1.5 \mathrm{ml} \mathrm{DIW}, 500 \mathrm{rpm}$. 
Table 2 Comparative experiment on acid added ${ }^{a}$

\begin{tabular}{llc}
\hline Entry & Acid added & Yield $/ \%$ \\
\hline 1 & PTSA-POM & 9.4 \\
2 & $\mathrm{AlCl}_{3} \cdot 6 \mathrm{H}_{2} \mathrm{O}$ & 50.8 \\
3 & $\mathrm{PTSA}-\mathrm{POM} / \mathrm{AlCl}_{3} \cdot 6 \mathrm{H}_{2} \mathrm{O}$ & 60.7 \\
& & \\
${ }^{a}$ Reaction conditions: $0.4 \mathrm{~g}$ glucose, $15 \mathrm{ml} \mathrm{GVL}$ and $1.5 \mathrm{ml} \mathrm{DIW}, 140{ }^{\circ} \mathrm{C}$, \\
60 min, $500 \mathrm{rpm}, \mathrm{PTSA}-\mathrm{POM}: 0.2 \mathrm{~g}, \mathrm{AlCl}_{3} \cdot 6 \mathrm{H}_{2} \mathrm{O}: 0.15 \mathrm{~g}$.
\end{tabular}

As for entry 1 and 2, we applied pure water and GVL as solvent under the optimum reaction condition, respectively. Apparently, very low yields of HMF were obtained both of them, only $1.2 \%$ in $16.5 \mathrm{ml}$ water and $3.5 \%$ in pure GVL. Moreover, reaction with much water could pull down the conversion of glucose conspicuously, from $98.1 \%$ to $14.3 \%$. From entry 3 to 11 , different water content $(0.5 \mathrm{ml}, 1.5 \mathrm{ml}, 3 \mathrm{ml})$ and fixed addition of $15 \mathrm{ml} \mathrm{GVL}$ solvent systems were evaluated at three time points (40 $\mathrm{min}, 60 \mathrm{~min}$ and $80 \mathrm{~min}$ ). On the overall trend, the yield of HMF was increased with the increase of water content from $0.5 \mathrm{ml}$ to $1.5 \mathrm{ml}$ and decreased afterwards with the water content continue increase to $3 \mathrm{ml}$. Besides, higher water content in the reactions would do harm to the conversion, $100 \%$ conversion of glucose was achieved in lower water content of $0.5 \mathrm{ml}$ and decreased with the increase of water content, which was in line with entry 1 and 2. Furthermore, the highest HMF yield was obtained under the optimized condition in $1.5 \mathrm{ml}$ $\mathrm{H}_{2} \mathrm{O} / 15 \mathrm{ml}$ GVL system (entry 7). In fact, though glucose
Table 5 Available chlorides compared with $\mathrm{AlCl}_{3} \cdot 6 \mathrm{H}_{2} \mathrm{O}^{a}$

\begin{tabular}{lllll}
\hline Entry & Chloride & Dosage $/ g$ & HMF yield $/ \%$ & Conversion \\
\hline 1 & $\mathrm{FeCl}_{3} \cdot 6 \mathrm{H}_{2} \mathrm{O}$ & 0.15 & 4.5 & 65.0 \\
2 & $\mathrm{CoCl}_{2} \cdot 6 \mathrm{H}_{2} \mathrm{O}$ & 0.15 & 5.4 & 93.7 \\
3 & $\mathrm{MnCl}_{2} \cdot 4 \mathrm{H}_{2} \mathrm{O}$ & 0.15 & 7.0 & 92.9 \\
4 & $\mathrm{MgCl}_{2} \cdot 6 \mathrm{H}_{2} \mathrm{O}$ & 0.15 & 13.3 & 91.1 \\
5 & $\mathrm{NiCl}_{2} \cdot 6 \mathrm{H}_{2} \mathrm{O}$ & 0.15 & 13.8 & 90.1 \\
6 & $\mathrm{SnCl}_{2} \cdot 2 \mathrm{H}_{2} \mathrm{O}$ & 0.15 & 14.2 & 84.1 \\
7 & $\mathrm{SnCl}_{4} \cdot 5 \mathrm{H}_{2} \mathrm{O}$ & 0.15 & 16.3 & 79.1 \\
8 & $\mathrm{CaCl}_{2}$ & 0.15 & 18.0 & 96.0 \\
9 & $\mathrm{NH}_{4} \mathrm{Cl}$ & 0.15 & 18.8 & 92.8 \\
10 & $\mathrm{CrCl}_{2}$ & 0.15 & 46.1 & 96.9 \\
11 & $\mathrm{CrCl}_{3} \cdot 6 \mathrm{H}_{2} \mathrm{O}$ & 0.15 & 60.4 & 91.8
\end{tabular}

${ }^{a}$ Reaction conditions: $0.4 \mathrm{~g}$ glucose, $0.2 \mathrm{~g}$ PTSA-POM, $1.5 \mathrm{ml}$ DIW, $15 \mathrm{ml} \mathrm{GVL}$, temperature: $140{ }^{\circ} \mathrm{C}$, time: $60 \mathrm{~min}, 500 \mathrm{rpm}$.

conversion decreased apparently with increase of water content from $1.5 \mathrm{ml}$ to $3 \mathrm{ml}$, the selectivity was almost keep the same, which indicated that when the water content has arrivals a certain value there is no significant effect on selectivity of HMF production. And the comparison with previous catalytic system are shown in Table 4 . From Table 4, we can also learn that low yields of HMF were obtained in pure water and GVL solvent (entry 1 and 2), which keeps consistent with the results we mentioned above.

In addition to the effect of reaction temperature, time and water content, here some valuable chlorides are compared with

Table 3 Effect of water content ${ }^{a}$

\begin{tabular}{|c|c|c|c|c|c|}
\hline 1 & $16.5 \mathrm{ml}$ water & 60 & 1.2 & 14.3 & 8.4 \\
\hline 2 & $16.5 \mathrm{ml} \mathrm{GVL}$ & 60 & 3.5 & 98.1 & 3.6 \\
\hline 4 & $0.5 \mathrm{ml} \mathrm{H}_{2} \mathrm{O}+15 \mathrm{ml} \mathrm{GVL}$ & 60 & 39.6 & 100 & 39.6 \\
\hline 5 & $0.5 \mathrm{ml} \mathrm{H}_{2} \mathrm{O}+15 \mathrm{ml} \mathrm{GVL}$ & 80 & 37.3 & 100 & 37.3 \\
\hline 6 & $1.5 \mathrm{ml} \mathrm{H}_{2} \mathrm{O}+15 \mathrm{ml} \mathrm{GVL}$ & 40 & 40.9 & 93.7 & 42.7 \\
\hline 9 & $3 \mathrm{ml} \mathrm{H}_{2} \mathrm{O}+15 \mathrm{ml} \mathrm{GVL}$ & 40 & 33.8 & 78.1 & 43.3 \\
\hline 10 & $3 \mathrm{ml} \mathrm{H}_{2} \mathrm{O}+15 \mathrm{ml} \mathrm{GVL}$ & 60 & 49.4 & 84.3 & 58.5 \\
\hline 11 & $3 \mathrm{ml} \mathrm{H}_{2} \mathrm{O}+15 \mathrm{ml} \mathrm{GVL}$ & 80 & 45.0 & 85.6 & 53 \\
\hline
\end{tabular}

${ }^{a}$ Reaction conditions: $0.4 \mathrm{~g}$ glucose, $0.2 \mathrm{~g}$ PTSA-POM, $0.15 \mathrm{~g} \mathrm{AlCl}{ }_{3} \cdot 6 \mathrm{H}_{2} \mathrm{O}$, temperature: $140{ }^{\circ} \mathrm{C}, 500 \mathrm{rpm}$.

Table 4 The comparison with previous catalytic system

\begin{tabular}{|c|c|c|c|c|c|}
\hline 1 & $\mathrm{TiO}_{2}$ & Water & 18.6 & 63.8 & 43 \\
\hline 2 & $\mathrm{SO}_{4}{ }^{2-} / \mathrm{ZrO}_{2}$ & DMSO & 19.2 & 95.2 & 44 \\
\hline 4 & PTA-PCP $(\mathrm{Cr})-\mathrm{SO}_{3} \mathrm{H}\left(\mathrm{Cr}^{3+}\right)$ & $\mathrm{H}_{2} \mathrm{O}-\mathrm{THF}-\mathrm{NaCl}$ & 45.3 & 100 & 46 \\
\hline 5 & $\mathrm{Zr}-\mathrm{P}-\mathrm{Cr}$ & {$[\mathrm{Bmim}] \mathrm{Cl}$} & 43.2 & 94.7 & 47 \\
\hline 6 & $\mathrm{LCC}^{a}$ & DMSO-[Bmim $] \mathrm{Cl}$ & 68 & 99 & 48 \\
\hline
\end{tabular}

${ }^{a}$ LCC $=$ lignin-derived carbonaceous catalyst. 
$\mathrm{AlCl}_{3} \cdot 6 \mathrm{H}_{2} \mathrm{O}$ and results were gathered in Table 5. As exhibited in Table 5, the HMF yield arranged from entry 1 to 11 in ascending order. Among those chlorides, $\mathrm{FeCl}_{3} \cdot 6 \mathrm{H}_{2} \mathrm{O}$ performed the worst both in HMF yield and glucose conversion, lowest $4.5 \% \mathrm{HMF}$ yield and $65.0 \%$ conversion were received. With regard to $\mathrm{CoCl}_{2} \cdot 6 \mathrm{H}_{2} \mathrm{O}$ and $\mathrm{MnCl}_{2} \cdot 4 \mathrm{H}_{2} \mathrm{O}$, HMF yield were both below $10 \%$ while the conversion of glucose were over 90\%. Entry 4, 5 and 8, 9, $\mathrm{MgCl}_{2} \cdot 6 \mathrm{H}_{2} \mathrm{O}$ and $\mathrm{NiCl}_{2} \cdot 6 \mathrm{H}_{2} \mathrm{O}, \mathrm{CaCl}_{2}$ and $\mathrm{NH}_{4} \mathrm{Cl}$ shows alike catalytic effects with almost the same results in $\mathrm{HMF}$ yield and glucose conversion. Unfortunately, except $\mathrm{CrCl}_{2}$ and $\mathrm{CrCl}_{3}$ $\cdot 6 \mathrm{H}_{2} \mathrm{O}$, low HMF yield were obtained in the presence of other chlorides in Table 5. HMF yield was obviously promoted to $46.1 \%$ in the presence of $\mathrm{CrCl}_{2}$, and higher glucose conversion 96.9\% was obtained. Compared with $\mathrm{CrCl}_{2}$, higher $\mathrm{HMF}$ yield $60.4 \%$ was gained in the case of $\mathrm{CrCl}_{3} \cdot 6 \mathrm{H}_{2} \mathrm{O}$ added, $91.8 \%$ of glucose conversion was observed in the meantime. Combined with previous reports illuminated that the hydrolyzed $\mathrm{Cr}$ (III) complex $\left[\mathrm{Cr}\left(\mathrm{H}_{2} \mathrm{O}\right) 5 \mathrm{OH}\right]^{2+}$ may provide a bifunctional site of Lewis acid-Brønsted base in glucose isomerization, and some water molecules in the first coordination sphere of Cr was displaced by glucose to promote the isomerization of glucose. ${ }^{41}$ Relate to $\mathrm{AlCl}_{3}$, the kinetics results in conjunction with reaction network expounded that the hydrolyzed $\mathrm{Al}(\mathrm{III})$ complex $\left[\mathrm{Al}(\mathrm{OH})_{2}(\mathrm{aq})\right]^{+}$is the most active $\mathrm{Al}$ species enable the isomerization of glucose. ${ }^{\mathbf{4 2}}$

Abovementioned, glucose was transformed into HMF in the first place and EMF was obtained with further etherification. In order to explore whether second organic solvent added will promote the production of EMF from glucose, in this section, DMSO, dioxane, THF, MIBK and GVL were added extra to ethanol $/ \mathrm{H}_{2} \mathrm{O}$ system, respectively. As Table 6 demonstrated, highest $\mathrm{HMF}$ yield of $48 \%$ was obtained while lowest EMF yield of only $2.9 \%$ was achieved in entry 1 (DMSO added). Other organic solvents, including dioxane, THF, MIBK and GVL showed low selectivity towards HMF and EMF, and it is indicated that there is useless with organic solvent added in the production of EMF from glucose. Therefore, in the following study, ethanol/ $\mathrm{H}_{2} \mathrm{O}$ solvent system without second organic solvent was employed in glucose-to-EMF.

Table 7 exhibits the effects of temperature and time on EMF production from glucose by conducting the reactions in ethanol $/ \mathrm{H}_{2} \mathrm{O}$ at $140{ }^{\circ} \mathrm{C}, 150{ }^{\circ} \mathrm{C}$, and $160{ }^{\circ} \mathrm{C}$. It can be observed that prolonged reaction time facilitated the production of EMF at $140{ }^{\circ} \mathrm{C}$ and $150{ }^{\circ} \mathrm{C}$. In comparison to lower temperatures, the

Table 6 Effect of second organic solvent added ${ }^{a}$

\begin{tabular}{lllll}
\hline Entry & Organic solvent & HMF/\% & EMF/\% & Conversion/\% \\
\hline 1 & DMSO & 48 & 2.9 & 100 \\
2 & Dioxane & 27.4 & 6.7 & 98.5 \\
3 & THF & 28.6 & 6.8 & 96.8 \\
4 & MIBK & 25.5 & 13.2 & 99.2 \\
5 & GVL & 21.6 & 15.7 & 97.9
\end{tabular}

${ }^{a}$ Reaction conditions: $0.4 \mathrm{~g}$ glucose, $0.2 \mathrm{~g}$ PTSA-POM, $0.15 \mathrm{~g}$ $\mathrm{AlCl}_{3} \cdot 6 \mathrm{H}_{2} \mathrm{O}, 1 \mathrm{ml} \mathrm{DIW}, 9 \mathrm{ml}$ ethanol and all the additive amount of organic solvent is $9 \mathrm{ml}$, temperature: $150{ }^{\circ} \mathrm{C}$, time: $30 \mathrm{~min}, 500 \mathrm{rpm}$.
Table 7 Effects of temperature and time on EMF production from glucose $^{a}$

\begin{tabular}{lllll}
\hline & $\begin{array}{l}\text { Time/ } \\
\text { Tin }\end{array}$ & $\begin{array}{l}\text { EMF } \\
\text { yield/\% }\end{array}$ & HMF yield/\% & $\begin{array}{l}\text { Glucose } \\
\text { conversion/\% }\end{array}$ \\
\hline 140 & 10 & 11.8 & 19.9 & 61.7 \\
140 & 15 & 15.6 & 19.2 & 65.9 \\
140 & 20 & 18.5 & 17.9 & 71.9 \\
140 & 25 & 19.9 & 17.8 & 78.6 \\
140 & 30 & 22.5 & 15.1 & 86.0 \\
150 & 10 & 21.0 & 19.5 & 93.5 \\
150 & 15 & 25.8 & 14.6 & 94.9 \\
150 & 20 & 26.4 & 14.2 & 96.3 \\
150 & 25 & 27.9 & 11.3 & 97.8 \\
150 & 30 & 30.6 & 11.5 & 97.8 \\
160 & 10 & 26.7 & 15.6 & 95.6 \\
160 & 15 & 28.8 & 11.7 & 98.2 \\
160 & 20 & 28.4 & 9.8 & 98.4 \\
160 & 25 & 28.5 & 8.8 & 99.2 \\
160 & 30 & 27.9 & 7.7 & 99.0 \\
& & & &
\end{tabular}

${ }^{a}$ Reaction conditions: $0.4 \mathrm{~g}$ glucose, $0.2 \mathrm{~g}$ PTSA-POM, $0.15 \mathrm{~g}$ $\mathrm{AlCl}_{3} \cdot 6 \mathrm{H}_{2} \mathrm{O}, 1 \mathrm{ml}$ DIW and $9 \mathrm{ml}$ ethanol, $500 \mathrm{rpm}$.

rate of EMF formation was rather quick when the temperature was raised to $160{ }^{\circ} \mathrm{C}$, and EMF yield kept at a relatively stable value as time increased. Highest EMF yield $30.6 \%$ was obtained at optimal temperature and reaction time $\left(150{ }^{\circ} \mathrm{C}, 30 \mathrm{~min}\right)$ with glucose conversion of $97.9 \%$.

Throughout the whole reaction progress, HMF was firstly produced and then etherified into EMF. As Table 7 showing, HMF yields gradually reduced with reaction time extended during all temperature. Both higher reaction temperature and longer reaction time facilitated the further conversion of HMF to $\mathrm{EMF}$, but HMF yield of $11.5 \%$ was still retained under the optimum reaction conditions, which highest EMF yield was achieved. Consistent with previous reports ${ }^{35,36,49}$ that as an intermediate product, HMF could not etherified into EMF completely. EMF production process has similar glucose conversion trend with HMF production, the longer the reaction time and the higher the reaction temperature, the higher the conversion of glucose.

\section{Conclusions}

In conclusion, successfully furans' (HMF and EMF) preparation from glucose were carried out in different solvents in the presence of $\mathrm{AlCl}_{3} \cdot 6 \mathrm{H}_{2} \mathrm{O}$ and a solid acid PTSA-POM, a series of influencing parameters were evaluated and significant results were acquired. The influence of water content has been studied and found that certain water content $(1.5 \mathrm{ml})$ in reaction system is beneficial to HMF production. Some other available chlorides were also explored to compare with $\mathrm{AlCl}_{3} \cdot 6 \mathrm{H}_{2} \mathrm{O}$ on the conversion of glucose into $\mathrm{HMF}$, the efficiency of $\mathrm{CrCl}_{2}$ and $\mathrm{CrCl}_{3}$ $\cdot 6 \mathrm{H}_{2} \mathrm{O}$ are better than others. And we further discovered that extra organic solvent (DMSO, dioxane, THF, MIBK and GVL) added to ethanol $/ \mathrm{H}_{2} \mathrm{O}$ system couldn't promote the production of EMF from glucose. Under the optimized conditions, $60.7 \%$ 
HMF yield with complete conversion of glucose was obtained in $\mathrm{GVL} / \mathrm{H}_{2} \mathrm{O}, 30.6 \%$ EMF yield and $11.5 \%$ HMF yield were achieved directly from glucose in ethanol/ $\mathrm{H}_{2} \mathrm{O}$, respectively. Finally, due to the characteristics of cheap and nontoxic, described aluminum system shows a promising prospect for application.

\section{Conflicts of interest}

There are no conflicts to declare.

\section{Acknowledgements}

This study was financially supported by the State Key Program of National Natural Science Foundation of China (51536009), Science and Technological Fund of Anhui Province for Outstanding Youth (1508085J01), the National Key Technology R\&D Program of China (No. 2015BAD15B06) and the international technology cooperation plan of Anhui (No. 1503062030).

\section{Notes and references}

1 A. Mukherjee, M.-J. Dumont and V. Raghavan, Biomass Bioenergy, 2015, 72, 143-183.

2 Y. S. Jang, B. Kim, J. H. Shin, Y. J. Choi, S. Choi, C. W. Song, et al., Biotechnol. Bioeng., 2012, 109, 2437-2459.

3 G. W. Huber, S. Iborra and A. Corma, Chem. Rev., 2006, 106, 4044-4098.

4 M. Dashtban, A. Gilbert and P. Fatehi, RSC Adv., 2014, 4, 2037-2050.

5 Y. Yang, W. T. Liu, N. N. Wang, H. J. Wang, Z. X. Song and W. Li, RSC Adv., 2015, 5, 27805-27813.

6 J. Heltzel and C. R. F. Lund, Catal. Today, 2016, 269, 88-92. 7 F. W. Lichtenthaler and S. Peters, C. R. Chim., 2004, 7, 65.

8 W. Hou, Q. Wang, Z. Guo, et al., Catal. Sci. Technol., 2017, 7(4), 1006-1016.

9 W. Zhang, J. Xie, W. Hou, et al., ACS Appl. Mater. Interfaces, 2016, 8(35), 23122-23132.

10 B. Puértolas, Q. Imtiaz, C. R. Müller, et al., ChemCatChem, 2017, 9(9), 1579-1582.

11 N. Shi, Q. Liu, L. Ma, T. Wang, Q. Zhang, Q. Zhang and Y. Liao, RSC Adv., 2014, 4, 4978-4984.

12 P. Zhou and Z. Zhang, Catal. Sci. Technol., 2016, 6, 3694.

13 T. F. Wang, M. W. Nolte and B. H. Shanks, Green Chem., 2014, 16, 548-572.

14 E. Nikolla, Y. Román-Leshkov, M. Moliner and M. E. Davis, ACS Catal., 2011, 1, 408-410.

15 X. Tong, Y. Ma and Y. Li, Appl. Catal., A, 2010, 385, 1.

16 M. Ohara, A. Takagaki, S. Nishimura and K. Ebitani, Appl. Catal., A, 2010, 383, 149-155.

17 R. S. Thombal and V. H. Jadhav, Appl. Catal., A, 2015, 499, 213-216.

18 V. I. Pârvulescu and C. Hardacre, Chem. Rev., 2007, 107, 2615-2665.

19 A. S. Amarasekara, Chem. Rev., 2016, 116, 6133-6183.

20 S. Zhang, J. Sun, X. Zhang, J. Xin, Q. Miao and J. Wang, Chem. Soc. Rev., 2014, 43, 7838-7869.
21 C. Maton, N. De Vos and C. V. Stevens, Chem. Soc. Rev., 2013, 42, 5963-5977.

22 S. Siankevich, Z. Fei, R. Scopelliti, et al., ChemSusChem, 2014, $7(6), 1647-1654$.

23 S. Siankevich, Z. Fei, R. Scopelliti, et al., ChemSusChem, 2016, 9(16), 2089-2096.

24 Z. Zhang and Z. K. Zhao, Bioresour. Technol., 2011, 102, 39703972.

25 J. H. He, Y. T. Zhang and E. Y. X. Chen, ChemSusChem, 2013, 6, 61-64.

26 C. M. Lew, N. Rajabbeigi and M. Tsapatsis, Ind. Eng. Chem. Res., 2012, 51, 5364-5366.

27 M. Mascal and E. B. Nikitin, Angew. Chem., Int. Ed., 2008, $47(41), 7924$.

28 P. Lanzafame, D. M. Temi, S. Perathoner, G. Centi, A. Macario, A. Aloise and G. Giordano, Catal. Today, 2011, 175(1), 435.

29 P. H. Che, F. Lu, J. J. Zhang, Y. Z. Huang, X. Nie, J. Gao and J. Xu, Bioresour. Technol., 2012, 119, 433.

30 M. Mascal and E. B. Nikitin, ChemSusChem, 2009, 2(9), 859. 31 N. Kumari, J. K. Olesen, C. M. Pedersen and M. Bols, Eur. J. Org. Chem., 2011, 2011(7), 1266.

32 B. Liu, et al., Fuel, 2013, 113, 625-631.

33 C. M. Lew, N. Rajabbeigi and M. Tsapatsis, Ind. Eng. Chem. Res., 2012, 51, 5364-5366.

34 Y. Yang, W. Liu, N. Wang and H. Wang, RSC Adv., 2015, 5, 27805.

35 Y. Yang, C. Hu and M. M. Abu-Omar, Bioresour. Technol., 2012, 116, 190-194.

36 H. Li and K. Santosh Govind, Energy Convers. Manage., 2014, 88, 1245-1251.

37 Z. Xu, W. Li, Z. Du, H. Wu, H. Jameel, H.-m. Chang and L. Ma, Bioresour. Technol., 2015, 198, 764-771.

38 D. Martin Alonso, S. G. Wettstein and J. A. Dumesic, Green Chem., 2013, 15, 584-595.

39 T. Zhang, W. Li, Z. Xu, Q. Liu, Q. Ma, H. Jameel, H.-m. Chang and L. Ma, Bioresour. Technol., 2016, 209, 108-114.

40 W. Li, Z. Xu, T. Zhang, et al., BioResources, 2016, 11(3), 58395853.

41 V. Choudhary, S. H. Mushrif, C. Ho, et al., J. Am. Chem. Soc., 2013, 135(10), 3997-4006.

42 J. Tang, L. Zhu, X. Fu, et al., ACS Catal., 2016, 7(1), 256-266.

43 X. Qi, M. Watanabe, T. M. Aida and R. L. Smith, Catal. Commun., 2008, 9, 2244-2249.

44 H. Pan, Y. Yang, D. Tong, X. Xiang and C. Hu, Catal. Commun., 2009, 10, 1558-1563.

45 L. Li, J. Ding, J.-G. Jiang, Z. Zhu and P. Wu, Chin. J. Catal., 2015, 36, 820-828.

46 D. Chen, F. Liang, D. Feng, M. Xian, H. Zhang, H. Liu and F. Du, Chem. Eng. J., 2016, 300, 177-184.

47 B. Liu, C. Ba, M. Jin and Z. Zhang, Ind. Crops Prod., 2015, 76, 781-786.

48 F. Guo, Z. Fang and T.-J. Zhou, Bioresour. Technol., 2012, 112, 313-318.

49 B. Liu and Z. Zhang, RSC Adv., 2013, 3, 12313-12319. 